\title{
A novel chlorinated norsesquiterpenoid and two related new metabolites from the soft coral Paralemnalia thyrsoides
}

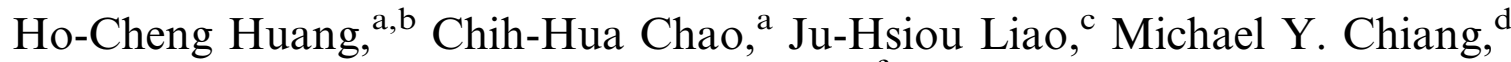 \\ Chang-Feng Dai, ${ }^{\mathrm{e}}$ Yang-Chang $\mathrm{Wu}^{\mathrm{f}}$ and Jyh-Horng Sheu ${ }^{\mathrm{a}, *}$ \\ ${ }^{a}$ Department of Marine Biotechnology and Resources, National Sun Yat-Sen University, Kaohsiung 804, Taiwan, ROC \\ ${ }^{\mathrm{b}}$ Department of Chemical and Materials Engineering, Cheng Shiu University, Kaohsiung 833, Taiwan, ROC \\ ${ }^{\mathrm{c}}$ Department of Chemistry, National Chung Cheng University, Chia-Yi 621, Taiwan, ROC \\ ${ }^{\mathrm{d}}$ Department of Chemistry, National Sun Yat-Sen University, Kaohsiung 804, Taiwan, ROC \\ ${ }^{\mathrm{e}}$ Institute of Oceanography, National Taiwan University, Taipei 106, Taiwan, ROC \\ ${ }^{\mathrm{f}}$ Graduate Institute of Natural Products, Kaohsiung Medical University, Kaohsiung 807, Taiwan, ROC
}

Received 12 August 2005; revised 6 September 2005; accepted 7 September 2005

Available online 23 September 2005

\begin{abstract}
A structurally unique chlorinated norsesquiterpenoid, paralemnolin A (1), along with two new metabolites, paralemnolin B (2) and C (3), have been isolated from the soft coral Paralemnalia thyrsoides. Their structures were determined by extensive spectroscopic analyses. Single-crystal X-ray diffraction analysis of $\mathbf{1}$ further establish the absolute stereochemistry of $\mathbf{1}$.
\end{abstract}

(C) 2005 Elsevier Ltd. All rights reserved.

Soft coral of the genus Paralemnalia have been found to be a rich source of bioactive secondary metabolites. ${ }^{1-4}$ During the course of our investigation on the bioactive chemical constituents from marine invertebrates, ${ }^{5-7}$ two new norsesquiterpenoids (1 and 2$)$, and one sesquiterpenoid (3) have been isolated from the soft coral Paralemnalia thyrsoides, collected by hand using scuba at Green Island, located off the southeast coast of Taiwan. We describe herein the structure elucidation of these compounds, and also the proposed biosynthesis pathway for the chlorinated metabolite 1 (Fig. 1).

The organism of $P$. thyrsoides was frozen immediately after collection and the freeze-dried organism was extracted sequentially with EtOAc. The EtOAc extract $(33.0 \mathrm{~g})$ was fractionated by open column chromatography on silica gel using $n$-hexane, $n$-hexane/EtOAc, and EtOAc/MeOH mixtures of increasing polarity. A fraction eluted with EtOAc/n-hexane $(1: 15)$ was further purified by normal-phase HPLC using EtOAc/ $n$-hexane (1:50) to afford compound $\mathbf{1}(20.9 \mathrm{mg})$. Compounds 2

Keywords: Paralemnolin A; Paralemnolin B; Paralemnolin C; Paralemnalia thyrsoides; Soft coral.

* Corresponding author. Tel.: +886 7 5252000x5030; fax: +886 7 5255020; e-mail: sheu@mail.nsysu.edu.tw

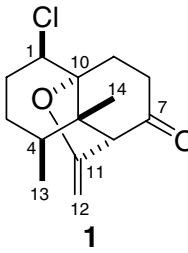<smiles>CC(=O)[C@H]1C(=O)CCC2=CCCC(C)C21C</smiles><smiles>CC(=O)OCC(C)C1=CC2(C)C(=CCCC2C)CC1</smiles><smiles>CC1CCC=C2CCC(C(C)(O)CO)=CC21C</smiles>

Figure 1. Structures of metabolites 1-4.

$(27.3 \mathrm{mg})$ and $3(35.5 \mathrm{mg})$ were eluted with EtOAc/ $n$-hexane (1:10) and further purified by normal-phase HPLC using EtOAc/n-hexane (1:30).

ESIMS of paralemnolin A (1) ${ }^{8}$ exhibited two ion peaks at $m / z 277[\mathrm{M}+\mathrm{Na}]^{+} / 279[\mathbf{M}+2+\mathrm{Na}]^{+}$(in a ratio ca. $1: 0.3)$ in accordance with the presence of one chlorine atom (Table 1). A molecular formula of $\mathrm{C}_{14} \mathrm{H}_{19} \mathrm{ClO}_{2}$ for 1 was established by HRESIMS, indicating five degrees of unsaturation. The NMR spectral data suggested the presence of one ketone $\left(\delta_{\mathrm{C}} 206.6 \mathrm{qC}\right)$, one 1-alkyl, 
Table 1. ${ }^{1} \mathrm{H}$ and ${ }^{13} \mathrm{C}$ NMR spectral data of compounds $1-3$

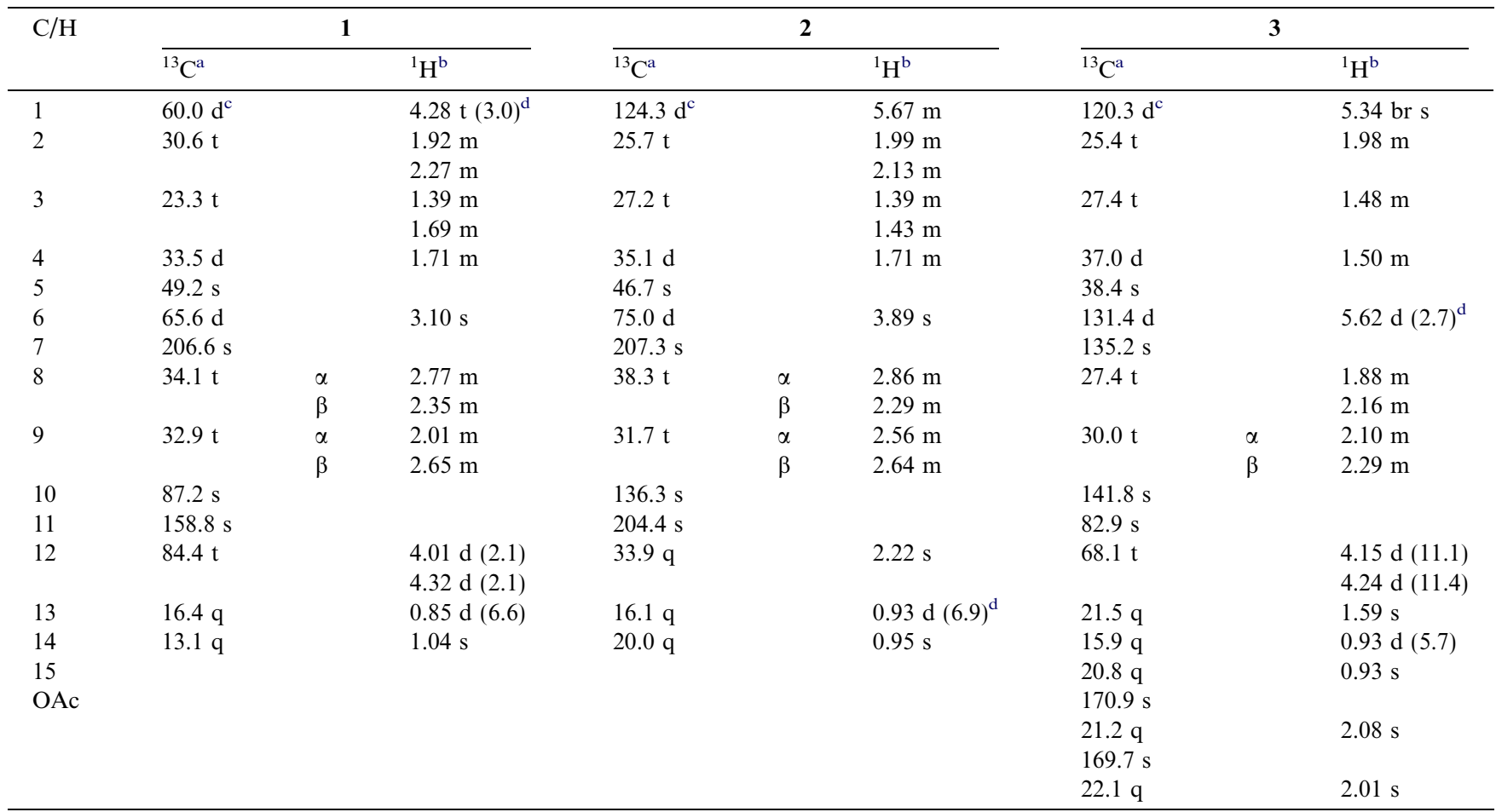

${ }^{\text {a }}$ Spectra recorded at $75 \mathrm{MHz}$ in $\mathrm{CDCl}_{3}$ at $25^{\circ} \mathrm{C}$.

${ }^{\mathrm{b}}$ Spectra recorded at $300 \mathrm{MHz}$ in $\mathrm{CDCl}_{3}$ at $25^{\circ} \mathrm{C}$.

${ }^{\mathrm{c}}$ Multiplicity are deduced by HSQC and DEPT spectra and indicated by usual symbol.

${ }^{\mathrm{d}} J$ value (in $\mathrm{Hz}$ ) in parentheses.

1-alkoxy-disubstituted carbon-carbon double bond $\left(\delta_{\mathrm{C}}\right.$ $158.8 \mathrm{qC}$ and $84.4 \mathrm{CH}_{2} ; \delta_{\mathrm{H}} 4.01$ and 4.32 , each d, $J=2.1 \mathrm{~Hz})$, one oxygenated quaternary carbon $\left(\delta_{\mathrm{C}}\right.$ $87.2)$, and one secondary alkyl chloride $\left(\delta_{\mathrm{C}} 60.0 ; \delta_{\mathrm{H}}\right.$ $4.28, \mathrm{dd}, J=3.0,3.0 \mathrm{~Hz}$ ). The above functionalities also account for two of the five degrees of unsaturation, suggesting a tricyclic structure in $\mathbf{1}$.

The gross structure of 1 was established by 2D NMR spectroscopic analyses. From ${ }^{1} \mathrm{H}-{ }^{1} \mathrm{H}$ COSY spectrum of $\mathbf{1}$, it was possible to establish the proton sequences by the following cross-peaks: $\mathrm{H}-1 / \mathrm{H}_{2}-2, \mathrm{H}_{2}-2 / \mathrm{H}_{2}-3$; $\mathrm{H}_{2}-3 / \mathrm{H}-4, \mathrm{H}-4 / \mathrm{H}_{3}-13, \mathrm{H}_{2}-8 / \mathrm{H}_{2}-9$ (Fig. 2). Its HMBC spectrum showed many informative correlations, such

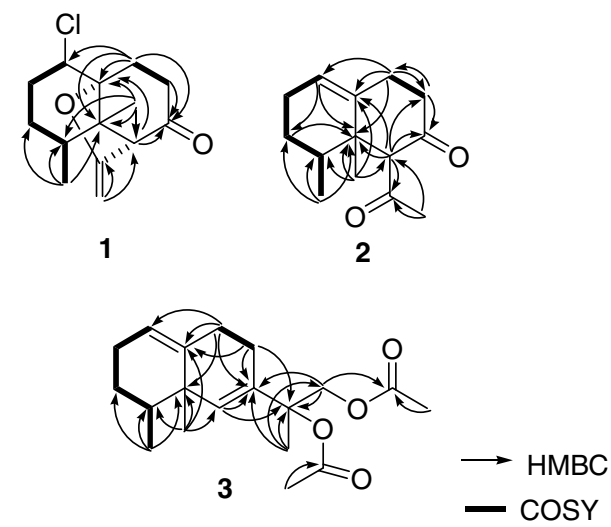

Figure 2. Selective ${ }^{1} \mathrm{H}_{-}{ }^{1} \mathrm{H}$ COSY and $\mathrm{HMBC}$ correlations of $\mathbf{1}-\mathbf{3}$. as $\mathrm{H}-6 / \mathrm{C}-7$ and $\mathrm{C}-10 ; \mathrm{H}_{2}-8 / \mathrm{C}-7$ and $\mathrm{C}-10 ; \mathrm{H}_{2}-9 / \mathrm{C}-1$, $\mathrm{C}-5, \mathrm{C}-7, \mathrm{C}-8$, and $\mathrm{C}-10 ; \mathrm{H}_{2}-12 / \mathrm{C}-11$ and $\mathrm{C}-6 ; \mathrm{H}_{3}-13 /$ $\mathrm{C}-3$, C-4, and $\mathrm{C}-5$; and $\mathrm{H}_{3}-14 / \mathrm{C}-4, \mathrm{C}-5, \mathrm{C}-6$, and C10 (Fig. 2). Thus, the unusual planar structure of 1 with an $\alpha$-methylene THF structural unit was established unambiguously.

The relative stereochemistry of $\mathbf{1}$ was elucidated from the NOE interactions observed in a NOESY experiment (Fig. 3). In the NOESY experiment of $1, \mathrm{H}_{3}-14$ was found to show NOE interactions with $\mathrm{H}-6, \mathrm{H}_{3}-13$, and one proton of $\mathrm{H}_{2}-9\left(\delta_{\mathrm{H}} 2.65, \mathrm{~m}\right)$, but not with $\mathrm{H}-1$ and $\mathrm{H}-4$. Furthermore, the other proton of $\mathrm{H}_{2}-9\left(\delta_{\mathrm{H}}\right.$ $2.01, \mathrm{~m}$ ) showed a NOE interaction with $\mathrm{H}-1$, suggesting that $\mathrm{H}_{3}-14, \mathrm{H}_{3}-13$, and $\mathrm{H}-6$ should be positioned on the same face and arbitrarily assigned as $\beta$-protons, and $\mathrm{H}-1$ and $\mathrm{H}-4$ were assigned as $\alpha$-protons. To confirm the structure of 1 and establish its absolute configuration, a single-crystal X-ray crystallographic analysis was undertaken. ${ }^{9}$ The crystal structure (ORTEP diagram)

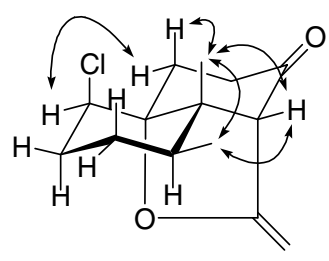

1

Figure 3. Key NOESY correlations of $\mathbf{1}$. 


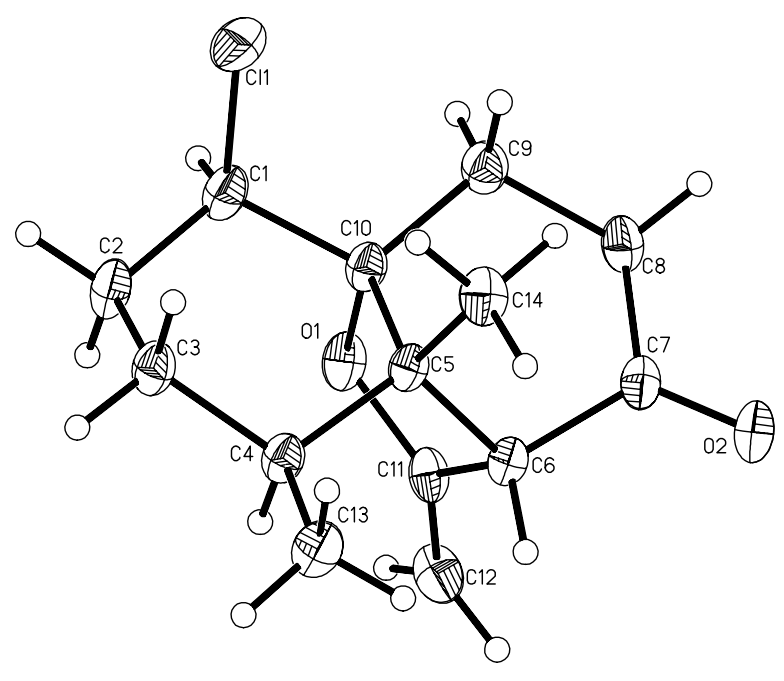

Figure 4. X-ray ORTEP diagram of 1.

is shown in Figure 4. The absolute stereochemistry was assigned on the basis of the Flack parameter, which refined to a value of 0.07(7). ${ }^{10}$ Thus, the structure of $\mathbf{1}$ was established unambiguously and the absolute configurations of $\mathrm{C} 1, \mathrm{C} 2, \mathrm{C} 5, \mathrm{C} 6$, and $\mathrm{C} 10$ were assigned as $1 R, 4 S, 5 S, 6 S$, and $10 R$, respectively.

Compound $2^{11}$ was obtained as a white powder. Its HREIMS exhibited a molecular ion peak at $\mathrm{m} / \mathrm{z}$ 220.1461 and established a molecular formula of $\mathrm{C}_{14} \mathrm{H}_{20} \mathrm{O}_{2}$, corresponding to five degrees of unsaturation. The NMR data showed the presence of two ketones ( $\delta_{\mathrm{C}} 207.3$ and 204.4 , each $\mathrm{qC}$ ), and one trisubstituted double bond $\left(\delta_{\mathrm{C}} 124.3 \mathrm{CH}, 136.3 \mathrm{qC}\right)$. The above functionality account for three of the five degrees of unsaturation, suggesting a bicyclic structure in 2.

To establish the proton correlations in 2 , the ${ }^{1} \mathrm{H}-{ }^{1} \mathrm{H}$ COSY spectrum was used to reveal the connectivities of $\mathrm{H}-1 / \mathrm{H}_{2}-2, \mathrm{H}_{2}-2 / \mathrm{H}_{2}-3, \mathrm{H}_{2}-3 / \mathrm{H}-4, \mathrm{H}-4 / \mathrm{H}_{3}-13$, and $\mathrm{H}_{2}-8 / \mathrm{H}_{2}-9$ (Fig. 2). These data, together with the ${ }^{1} \mathrm{H}-{ }^{13} \mathrm{C}$ long-range correlations observed in the HMBC experiment (Fig. 2), established the carbon skeleton of 2. The position of the acetyl group at C-6 was confirmed by the key HMBC correlations from $\mathrm{H}_{3}-12$ to $\mathrm{C}-11$ and C-6. The other ketone positioned at C-7 was confirmed by the following HMBC cross-peaks: H-6/C-5, C-7, C-8, and $\mathrm{C}-10$; and $\mathrm{H}_{2}-8 / \mathrm{C}-7$, C-9, and $\mathrm{C}-10$. The above observations and other HMBC correlations as shown in Figure 2, established the planar structure of 2. Furthermore, the NOE correlations between $\mathrm{H}_{3}-14$ and $\mathrm{H}_{3}-13$, and $\mathrm{H}_{3}-14$ and $\mathrm{H}-6$ suggested the $\beta$-orientation of these protons. Thus, the structure of $\mathbf{2}$ was fully established.

Compound $\mathbf{3}^{12}$ was isolated as a colorless oil. The HRESIMS of 3 established a molecular formula of $\mathrm{C}_{19} \mathrm{H}_{28} \mathrm{O}_{4}$, implying six degrees of unsaturation. By comparison of the NMR spectral data of $\mathbf{3}$ with those of a known metabolite $4,{ }^{13}$ it was found that hydroxy groups attached to C-11 and C-12 in $4\left(\delta_{\mathrm{C}-11} 75.1, \delta_{\mathrm{C}-12} 68.4\right.$,
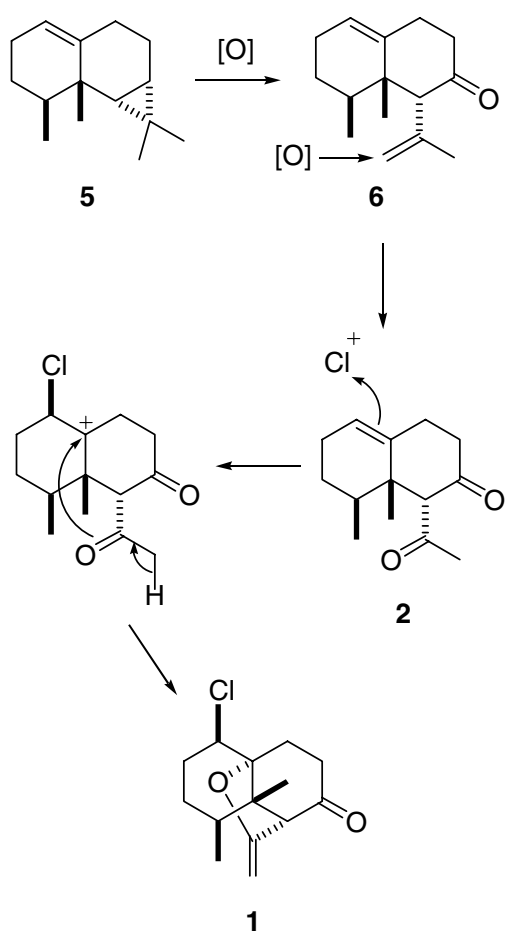

Scheme 1. Proposed biosynthesis pathway of $\mathbf{1}$.

and $\delta_{\mathrm{H}} 3.42$ and 3.61) were converted to acetoxy groups in $3\left(\delta_{\mathrm{C}-11} 82.9, \delta_{\mathrm{C}-12} 68.1, \delta_{\mathrm{H}} 4.15\right.$ and 4.24). The NOE correlations between $\mathrm{H}_{3}-15$ and $\mathrm{H}_{3}-14$ suggested these protons were located on the same face in the molecule of 3.

On the basis of a biosynthetic reaction suggested by Bowden et al., ${ }^{4}$ a biogenetic precursor 1(10)-aristolene (5) could be transformed into a diene intermediate (6). It was considered to be possible that oxidative cleavage at double bond of the isopropenyl group of $\mathbf{6}$ could afford metabolite 2 (Scheme 1). Furthermore, the proposed biosynthetic pathway of $\mathbf{1}$ and the biogenetic relationship between $\mathbf{1}$ and $\mathbf{2}$ was shown also in Scheme 1 . This pathway involves initial chlorination at C-1 of $\mathbf{2}$ to form a carbonium ion with a positive charge at C10. Subsequent enolization of the acetyl group and the following cyclization of the enol hydroxyl with C-10 would lead to the formation of $\mathbf{1}$.

Preliminary biological activity screening revealed that these three compounds are not active against the growth of a limited panel of cancer cell lines, including A549 (human lung carcinoma), HepG2 (human hepatocellular carcinoma), and MAD-MB-231 (human breast carcinoma) cells. The results of further biological activity screening will be reported elsewhere in the future.

\section{Acknowledgments}

Financial support was provided by National Science Council of Taiwan (NSC93-2113 -M-110-007) awarded to J.-H. Sheu. 


\section{References and notes}

1. Blunt, J. W.; Copp, B. R.; Munro, M. H. G.; Northcote, P. T.; Prinsep, M. R. Nat. Prod. Rep. 2004, 21, 149, and literature cited in previous reviews.

2. Su, J.-Y.; Zhong, Y.-L.; Zeng, L.-M. J. Nat. Prod. 1993, 56, 288-291.

3. Izac, R.-R.; Schneider, P.; Swain, M.; Fenical, W. Tetrahedron Lett. 1982, 23, 817-820.

4. Bowden, B.-F.; Coll, J. C.; Mitchell, S.-J. Aust. J. Chem. 1980, 33, 885-890.

5. Sheu, J.-H.; Chao, C.-H.; Wang, G.-H.; Hung, K.-C.; Duh, C.-Y.; Chiang, M.-Y.; Wu, Y.-C.; Wu, C.-C. Tetrahedron Lett. 2004, 45, 6413-6416.

6. Sheu, J.-H.; Hung, K.-C.; Wang, G.-H.; Duh, C.-Y. J. Nat. Prod. 2000, 63, 1603-1607.

7. Chao, C.-H.; Huang, L.-F.; Yang, Y.-L.; Su, J.-H.; Wang, G.-H.; Chiang, M. Y.; Wu, Y.-C.; Dai, C.-F.; Sheu, J.-H. J. Nat. Prod. 2005, 68, 880-885.

8. Paralemnolin A (1): colorless crystal; mp $96-98^{\circ} \mathrm{C}$; $[\alpha]_{\mathrm{D}}^{25}-133 \quad\left(c \quad 0.82, \mathrm{CHCl}_{3}\right) ; \quad \mathrm{IR}(\mathrm{KBr}) v_{\max } 1722$, $1674 \mathrm{~cm}^{-1}$; ${ }^{1} \mathrm{H}$ NMR and ${ }^{13} \mathrm{C}$ NMR data, see Table 1;
ESIMS $\mathrm{m} / \mathrm{z}$ (relative intensity) $277 / 279[\mathrm{M}+\mathrm{Na}]^{+}(1 / 0.3)$; HRESIMS $m / z \quad 277.0973 \quad[\mathrm{M}+\mathrm{Na}]^{+}$(calcd for $\left.\mathrm{C}_{14} \mathrm{H}_{19} \mathrm{ClO}_{2} \mathrm{Na}, 277.0971\right)$.

9. Crystallography data (excluding structure factors) of $\mathbf{1}$ have been deposited with the Cambridge Crystallographic Data Center as supplementary publication numbers CCDC280602. Copies of the data can be obtained, free of charge, on application to CCDC, 12 Union Road, Cambridge CB2 1EZ, UK [fax: +44(0)-1223-336033 or e-mail: deposit@ccdc.cam.ac.uk].

10. Flack, H. D. Acta Crystallogr. 1983, A39, 876-881

11. Paralemnolin $\mathrm{B}(2)$ : white powder; $\operatorname{mp} 47-49{ }^{\circ} \mathrm{C} ;[\alpha]_{\mathrm{D}}^{25}-600$ $\left(c 1.46, \mathrm{CHCl}_{3}\right)$; IR (KBr) $v_{\max } 1697 \mathrm{~cm}^{-1} ;{ }^{1} \mathrm{H}$ NMR and ${ }^{13} \mathrm{C}$ NMR data, see Table 1; EIMS $\mathrm{m} / z 220[\mathrm{M}]^{+}$; HREIMS $m / z 220.1461[\mathrm{M}]^{+}$(calcd for $\mathrm{C}_{14} \mathrm{H}_{20} \mathrm{O}_{2}, 220.1463$ ).

12. Paralemnolin $\mathrm{C}(3)$ : colorless oil; $[\alpha]^{25}-142$ (c 1.08 , $\left.\mathrm{CHCl}_{3}\right)$; IR (KBr) $v_{\max } 1745 \mathrm{~cm}^{-1} ;{ }^{1} \mathrm{H} \mathrm{NMR}$ and ${ }^{13} \mathrm{C}$ NMR data, see Table 1; ESIMS $m / z 343[\mathrm{M}+\mathrm{Na}]^{+}$; HRESIMS $m / z \quad 343.1887 \quad[\mathrm{M}+\mathrm{Na}]^{+}$(calcd for $\left.\mathrm{C}_{19} \mathrm{H}_{28} \mathrm{O}_{4} \mathrm{Na}, 343.1885\right)$.

13. Izac, R.-R.; Fenical, W.; Tagle, B.; Clardy, J. Tetrahedron 1981, 37, 2569-2573. 